\title{
Endoplasmic Reticulum Stress and Unfolded Protein Response in Breast Cancer: The Balance between Apoptosis and Autophagy and Its Role in Drug Resistance
}

\author{
Lorenza Sisinni $^{1, \dagger}{ }^{+}$Michele Pietrafesa ${ }^{1,+}$, Silvia Lepore $^{1}$, Francesca Maddalena ${ }^{1}$, \\ Valentina Condelli ${ }^{1}$, Franca Esposito ${ }^{2}(\mathbb{D}$ and Matteo Landriscina $1,3, * \mathbb{D}$ \\ 1 Laboratory of Pre-Clinical and Translational Research, IRCCS, Referral Cancer Center of Basilicata, \\ 85028 Rionero in Vulture, Italy; lorisi@hotmail.com (L.S.); michele.pietrafesa@crob.it (M.P.); \\ silvia.lepore@crob.it (S.L.); francesca.maddalena@crob.it (F.M.); valentina.condelli@crob.it (V.C.) \\ 2 Department of Molecular Medicine and Medical Biotechnology, University of Napoli Federico II, \\ 80131 Naples, Italy; franca.esposito@unina.it \\ 3 Medical Oncology Unit, Department of Medical and Surgical Sciences, University of Foggia, 71100 Foggia, Italy \\ * Correspondence: matteo.landriscina@unifg.it; Tel.: +39-0881-736426 \\ + These authors contributed equally.
}

Received: 14 January 2019; Accepted: 15 February 2019; Published: 16 February 2019

\begin{abstract}
The unfolded protein response (UPR) is a stress response activated by the accumulation of unfolded or misfolded proteins in the lumen of the endoplasmic reticulum (ER) and its uncontrolled activation is mechanistically responsible for several human pathologies, including metabolic, neurodegenerative, and inflammatory diseases, and cancer. Indeed, ER stress and the downstream UPR activation lead to changes in the levels and activities of key regulators of cell survival and autophagy and this is physiologically finalized to restore metabolic homeostasis with the integration of pro-death or/and pro-survival signals. By contrast, the chronic activation of UPR in cancer cells is widely considered a mechanism of tumor progression. In this review, we focus on the relationship between ER stress, apoptosis, and autophagy in human breast cancer and the interplay between the activation of UPR and resistance to anticancer therapies with the aim to disclose novel therapeutic scenarios. The hypothesis that autophagy and UPR may provide novel molecular targets in human malignancies is discussed.
\end{abstract}

Keywords: endoplasmic reticulum stress; unfolded protein response; breast cancer; apoptosis; autophagy; drug resistance; hormone therapy

\section{Introduction}

The endoplasmic reticulum (ER) is an intracellular organelle that contributes to the production and folding of cellular proteins and is involved in the maintenance of cellular homeostasis and the subtle balance between health and disease [1]. The ER is responsible for synthesis, maturation, folding, quality control, and degradation of secreted and transmembrane proteins, and guarantees that only correctly folded proteins can reach their cell compartment [1]. A specific ER stress pathway is activated when unfolded or misfolded proteins accumulate within the ER lumen [1], known as the unfolded protein response (UPR). Wrongly folded proteins can accumulate when ER protein folding capacity is overwhelmed by cellular demand and/or cellular energy availability is not sufficient to correctly fold proteins synthesized into the ER [1]. The UPR helps cells to restore homeostasis using different mechanisms: (i) by attenuating protein synthesis, (ii) by increasing the capacity of the ER to fold proteins and clear unfolded/misfolded proteins [2], and (iii) by activating chaperones/heat shock proteins to assist toward misfolded protein accumulation and cell cycle arrest [2]. 
The UPR leads to changes in activities of key regulators, integrating pro-death and pro-survival signals and functions, thus determining cell fate. This process is driven by signals that crosstalk among plasma membrane, ER, cytosol, mitochondria, and nucleus, leading to changes in cellular metabolism necessary to enable induction or repression of apoptosis and/or autophagy. The pathologic activation of the UPR is involved in the pathogenesis of several human diseases: cell death initiation has implications mainly in metabolic, neurodegenerative, and inflammatory diseases [3], whereas survival signals are relevant in malignancies [4]. In breast tumors, stress arises from hypoxia and nutrient deprivation induced by cytotoxic and endocrine therapeutic interventions and several lines of evidence suggest that chronic activation of the UPR is associated with therapy resistance and disease recurrence $[5,6]$. Moreover, several studies linked estrogen receptor signaling to the regulation of the UPR $[7,8]$ : the glucose regulated protein 78 (GRP78), also called binding immunoglobulin protein (BiP), and the $\mathrm{x}$-box binding protein 1 (XBP1) are upregulated in endocrine- and chemotherapy-resistant breast cancers [7,9-13]. In such a context, molecular mechanisms leading to chronic activation of UPR are currently viewed as novel potential targets to restore drug sensitivity.

\section{ER Function: From Protein Production to UPR}

The mail function of ER is to ensure an efficient quality control to guarantee that only properly folded proteins can reach their final destination [14]. This maturation process is finely regulated by specific chaperones of the reticular compartment. They can be gathered into three groups: GRP78 and GRP94 that facilitate the assembly and folding of unspecific proteins [15]; calnexin and calreticulin, lectins involved in the maturation process of glycoproteins [16]; and Heat shock protein 47 (Hsp47) specifically for collagen [17]. Furthermore, there is another functional class of enzymes that catalyzes the formation and/or disruption of disulfide bonds, such as protein disulfide isomerases (PDIs) [15]. Under physiological conditions, damaged or incorrectly folded proteins are sequestered and eliminated through a process called endoplasmic reticulum-associated protein degradation (ERAD) [18]. Calcium has a central role in this process, since reticular chaperones have different values of affinity for calcium and their activity is modulated by fluctuations in the concentration of this ion [19]. Moreover, the folding process and any refolding occur with a net energy consumption in the form of ATP, so any event that involves a modification of intracellular energy levels can block their activity. The activity of PDIs involves a net production of ROS, and when the capacity of the reticular antioxidant systems is saturated, the reticular homeostasis is compromised [20]. These stress stimuli are able to undermine the correct function of protein complexes used to guarantee the correct folding of newly synthesized proteins with consequential aggregation and protein misfolding, a condition better defined as "reticular stress" $[19,20]$. In tumors, the rapid and uncontrolled cell growth can alter reticular homeostasis due to intrinsic factors, as the increased rate of synthesis of oncoproteins, and extrinsic factors, such as nutrients and oxygen deprivation, which results in the establishment of a hypoxic state, acidosis, and starvation [14]. In order to struggle "protein-toxic" stress, cells respond by activating a signaling pathway called UPR that results in the reprogramming of a series of events that can be pro-survival or pro-death, depending on the extent of the damage or the length of the stress [21].

\subsection{UPR Signaling}

Three major sensors control the UPR: the inositol requiring enzyme 1 (IRE1), the protein kinase RNA-activated (PKR)-like ER kinase (PERK), and the activating transcription factor 6 (ATF6). These stress sensors are bound by the ER chaperone, GRP78/BiP, and are maintained in an inactive state [22,23] (Figure 1). Misfolded proteins, stored in the ER, activate GRP78/BiP, induce the expression of ER-resident chaperones, and transiently decrease protein synthesis. The UPR rebalances protein load and folding, thus restoring ER capacity, and for this reason, it is considered an adaptive and cytoprotective process [24]. The starting signal for UPR is the activation and homo-dimerization of PERK and IRE1, subsequently to the trans-autophosphorylation of their cytoplasmic components, whereas the activation of ATF6 occurs with its translocation to the Golgi apparatus (Figure 1). GPR78 
has a crucial role in cell protection against ER stress: it is associated with the luminal domains of the UPR transducers, preventing PERK and IRE1 homo-dimerization, and impeding the translocation of ATF6 to the Golgi. When misfolded proteins increase in the ER lumen, GRP78 is recruited for protein folding, prevents $\mathrm{Ca}^{2+}$ release into the cytosol, thus inhibiting the cell death cascade [25], and releases UPR sensors. Upon release by GRP78, ATF6 is cleaved in the Golgi apparatus, translocates to the nucleus, and induces the expression of genes coding for enzymes responsible of protein folding and ER-resident molecular chaperones [26-28], including GRP78, among others [29] (Figure 1).

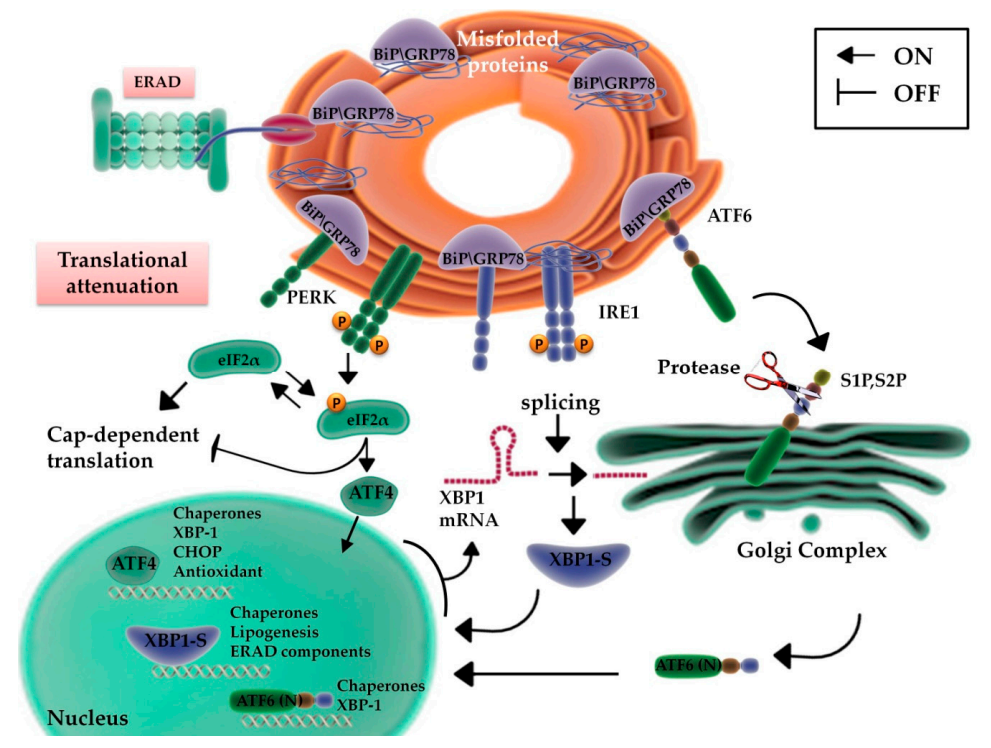

Figure 1. Unfolded protein response activation during Endoplasmic Reticulum (ER) stress conditions. Accumulation of misfolded proteins in endoplasmic reticulum induces the activation of three ER stress sensors: the activating transcription factor 6 (ATF6), the inositol requiring enzyme 1 (IRE1), and the protein kinase RNA-activated (PKR)-like ER kinase (PERK). Under physiological conditions, their activation is prevented by binding to BiP/GRP78. When misfolded proteins increase in the ER, GRP78 is recruited for protein folding and releases Unfolded protein response (UPR) sensors. Consequently, ATF6 is transported to the Golgi and activated, following cleavage by Site- 1 protease (S1P) and Site-2 protease (S2P). Cleaved ATF6 (ATF6(N)) behaves as a transcription factor, inducing the expression of ER chaperones and the transcription factor, XBP1. Activated IRE1 induces the splicing of XBP1 mRNA, and the resulting spliced XBP1 protein (XBP1s) translocates to the nucleus and regulates the transcription of genes involved in ER-associated degradation (ERAD). PERK, when activated, hampers general protein synthesis via the phosphorylation of eIF2 $\alpha$ and enables the translation of ATF4. Under physiological conditions, damaged or incorrectly folded proteins are sequestered and eliminated through endoplasmic reticulum-associated protein degradation (ERAD).

PERK activation induces the serine-phosphorylation of eIF2 $\alpha$ and inhibits the translational activity of eIF2B, with the consequent block of protein synthesis [30]. During ER stress, this process reduces the protein overload and the accumulation of misfolded proteins, allowing the synthesis of Cap-independent transcripts [31] (Figure 1).

The third regulator of UPR is IRE1, whose endoribonuclease activity is responsible for the production of a splicing variant of XBP1, called XBP1s [32]. This transcriptional factor alleviates the ER stress through the activation of a series of downstream genes involved in protein secretion, maturation and degradation [32] (Figure 1).

Misfolded and aberrant proteins are degraded using a systemic pathway: detrimental proteins are tagged by chaperones, poly-ubiquitinated, and degraded in the $26 \mathrm{~S}$ subunit of the proteasome [33], directing the cell towards adaptive UPR [34]. Afterwards, if the cell is able to overcome the ER stress condition, a series of pro-survival events are activated, whereas if the stress condition 
persists, UPR undertakes the pro-death pathway. It is important to note that several human cancers (i.e., hepatocellular, lung, pancreatic, and breast cancer) are characterized by prolonged and uncontrolled activation of UPR and this promotes tumor growth and therapy resistance [35]. Thus, UPR is presently evaluated as a molecular target for therapeutic interventions aimed at modulating UPR as a cancer-killing strategy.

\subsection{The Unfolded Protein Response and the Balance between Autophagy, Survival, and Apoptosis}

The UPR regulates different pathways to restore metabolic homeostasis, blocking or promoting cell death based on its capacity to remove the stress condition or not. This adaptive process involves the regulation and the reciprocal integration of autophagy and apoptosis. Indeed, autophagy is also associated to both cell survival and death [36]: pro-death signaling is usually activated to eliminate cells deprived of key proteins or altered by incorrect secretion of hormones, growth factors, or accumulation of misfolded proteins, or subjected to DNA damage or oxidative stress [37]. This is a natural process through which cells recycle organelles and damaged or not necessary proteins [38]. The process starts with (i) the formation of double membrane structures which phagocytize targeted molecules, (ii) the appearance of cytoplasmic vacuoles, and (iii) the increased cleavage of microtubule-associated protein 1 light chain 3 (LC3), following its transcription by PERK/eIF2 $\alpha /$ ATF4 axis [39] (Figure 2). In physiological conditions, basal autophagy removes damaged organelles or old proteins, releasing into the cytosol degradation products coming from specific organelles, easily identifiable as mitochondria (mitophagy), ribosomes (ribophagy), and ER (reticulophagy) [39]. Similar to UPR, autophagy is associated to cell survival [40], being finalized to correct the energy imbalance, establish correct protein folding, and recycle cellular contents [41]. However, the persistence of the autophagic process is no longer maintained for survival; it could evolve in apoptotic or autophagic cell death and this may reflect the necessity to eliminate cells with altered key proteins or subjected to oxidative stress and DNA damage [42].

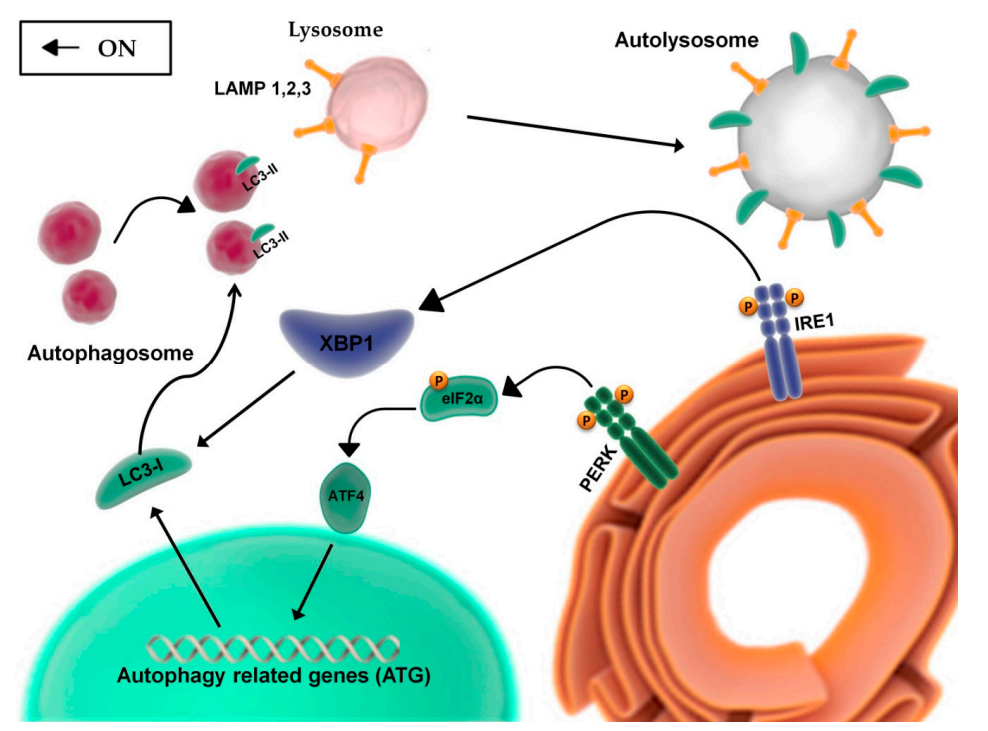

Figure 2. Crosstalk between UPR and autophagy. The autophagic process involves a molecular crosstalk with UPR transducers: (i) PERK/eIF2 $\alpha$ pathway induces the expression of autophagy-related genes through ATF4; and (ii) the activation of XBP1, downstream to IRE1, favors the recruitment of soluble LC3-I to the membranous structures, giving rise to the autophagosome, and to its transformation into LC3-II, the membrane-associated form of LC3-I. The autophagosome complex, conjugated with LC3-II, captures organelles or molecules destined for degradation and merges with lysosome-expressing integral membrane proteins, LAMPs $(1,2,3)$, and this leads to the formation of the autolysosome complex. 
Two signaling pathways are responsible of the apoptotic cascade: the intrinsic or mitochondrial pathway and the extrinsic or death receptor pathway. During the activation of the intrinsic pathway, apoptotic stimuli induce changes in the mitochondrial inner membrane potential causing the exposure of pro-apoptotic proteins [43]. $\mathrm{Ca}^{2+}$ is released from the ER into the cytosol and activates caspase-12; PERK phosphorylates the alpha subunit of eIF2 $\alpha$ and this in turn activates ATF4, which acts on the transcription factor CCAAT-enhancer-binding protein homologous protein $(\mathrm{CHOP})$ promoter [44] (Figure 1). These factors stimulate the expression of pro-apoptotic proteins with the activation of DNA damage inducible protein 34 (GADD34), leading to an increase in protein synthesis [45,46], the downregulation of antiapoptotic proteins, and induce the release of cytochrome $\mathrm{c}$ into the cytosol activating caspase- 3 and caspase- 9 signaling $[47,48]$. In this scenario, it should be emphasized that PERK and ATF4 are fundamentally pro-survival pathways, but they can also promote apoptosis through the activation of CHOP, the main mediator of apoptosis induced by the UPR [49,50].

Different is the molecular mechanism leading to activation of the extrinsic pathway. Pro-death extracellular stimuli activate members of the tumor necrosis factor receptor superfamily and this leads to induction of the apoptotic cascade [51]. However, intracellular stimuli, during the ER stress process, are also responsible for the induction of the extrinsic pathway through a specific activation of c-Jun N-terminal kinase (JNK) [52]. These signals involve primarily IRE1 pathway, which (i) overcomes the transcriptional blockade induced by PERK [53], (ii) digests specific miRNAs through its endoribonuclease domain (IRE1-dependent decay of mRNA, RIDD) [54], and iii) recruits tumor necrosis factor receptor-associated 2 (TRAF2) with downstream activation of Apoptosis signal-regulating kinase 1 (ASK1), JNK [52], and p38 MAPK pathways [55] (Figure 3). JNK phosphorylation regulates the expression of specific Bcl-2 family members, favoring the activation of proapoptotic genes and the parallel downregulation of antiapoptotic proteins [56,57]. On one hand, the p38 MAPK pathway promotes the phosphorylation of CHOP serine residues 78 and 81 , increasing its transcriptional activity [58], and this favors the transcription of proapoptotic client genes, such as DR5 (TRAIL Receptor-2); tribbles-related protein 3 (TRB3); BH3-only proteins of the Bcl-2 family Bim, Bak, Bax, PUMA, and NOXA; and the downregulation of anti-apoptotic genes of the same family (Figure 3). Another CHOP client gene is GADD34, which encodes for a phosphatase, is able to dephosphorylate eIF2 $\alpha$, and thus, overcome PERK-induced transcriptional block, further promoting the synthesis of pro-apoptotic proteins $[59,60]$. Furthermore, CHOP induces the expression of Ero1 $\alpha$, which promotes cell death through the hyperoxidation of ER proteins. The increased production of ROS induces a shift in the balance between reduced and oxidized residues of the cysteine domains of IP3R and this event favors calcium-dependent apoptosis [61].

Overall, the activation of transcription factors, kinase-dependent signaling pathways, and the regulation of members of the Bcl-2 family leads to activation of initiators caspases 8 and 9, and execution caspases $3,6,7$, and 12 . Among these, caspase 12 begins the final execution phase, even if its activation mechanisms are not completely understood [50,62].

In the context of cancer, some of the key components of the UPR signaling are up-regulated and chronically activate these adaptive mechanisms, thus promoting tumor progression and survival [63]. In such a view, new evidence connects the UPR with specific hallmarks of cancer, postulating new possible regulatory pathways, and suggests that this adaptive pathway may provide a mechanism of control of specific cancer functions, as capacity to adapt to hostile environments, escape apoptosis, and anticancer agents and reprogram cell metabolism [4]. 


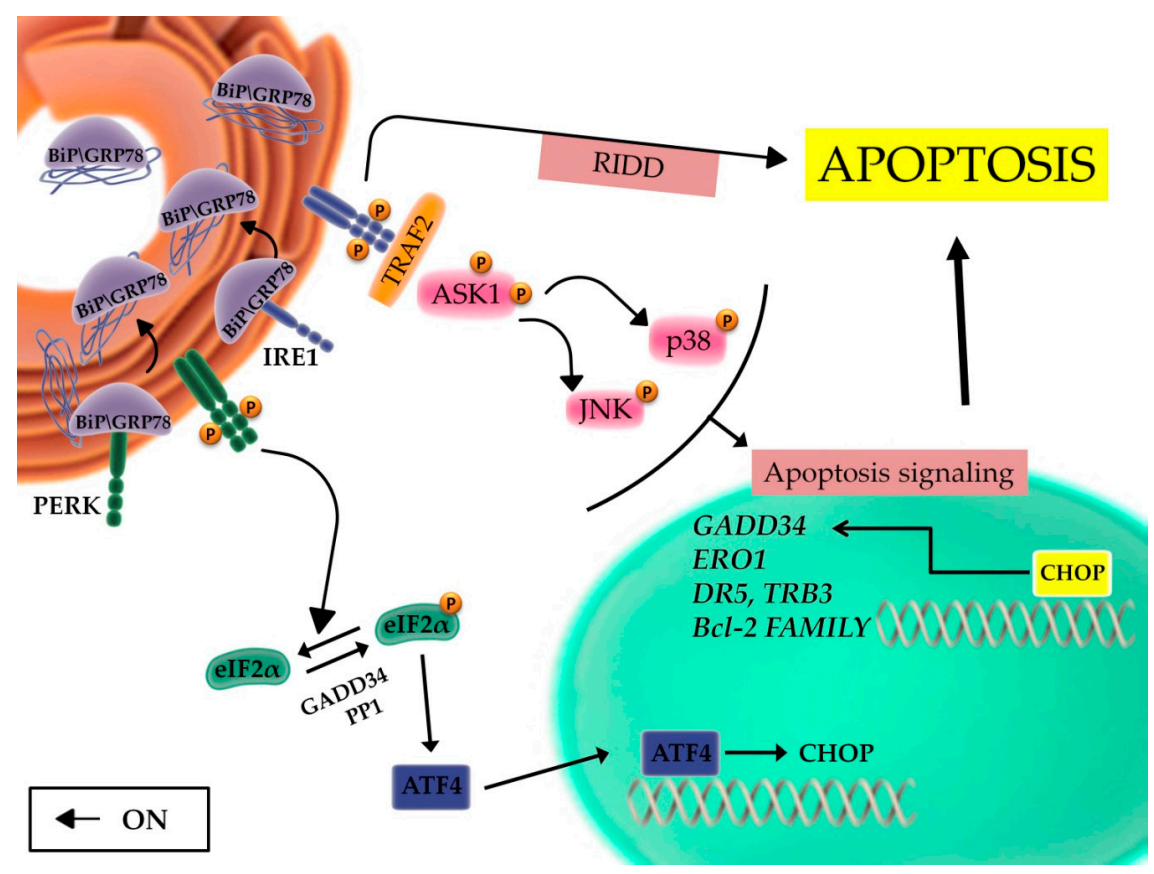

Figure 3. Apoptotic signaling during ER stress. Prolonged or severe ER stress conditions induce apoptotic signaling through the activation of IRE1 and PERK pathways. Upon activation of the IRE1 pathway, IRE1 recruits TRAF2 and ASK1 on the ER membrane and this induces the apoptotic response upon modulation of the balance between proapoptotic and antiapoptotic genes. Furthermore, IRE1 digests specific miRNAs through its endoribonuclease domain (IRE1-dependent decay of mRNA, RIDD). PERK pathway activates ATF4, which in turn enhances the transcription of CHOP, a transcription factor responsible for the regulation of many proapoptotic genes (i.e., GADD34, ERO1, DR5, TRB3, Bcl-2 family genes). In this complex scenario, GADD34 and PP1 promote the dephosphorylation of eIF $2 \alpha$, leading to enhanced protein synthesis and the increase of protein load into the ER.

\subsection{The Role of the Inflammatory Signaling Cascade during the UPR}

Emerging evidences suggest that there are points of connection between the UPR and the inflammatory cascade [52]. Indeed, ER stress induces inflammatory signaling and modulates nuclear factor- $\mathrm{kB}$ (NF- $\mathrm{kB}$ ) activity [64], the principal transcriptional regulator of pro-inflammatory pathways [64]. In normal conditions, NF- $\mathrm{BB}$ is in an inactive status through binding with its constitutively expressed inhibitor, I $\mathrm{\kappa} B \alpha$. Multiple cellular pathways activate I $\kappa \mathrm{B} \alpha$ kinase (IKK), which phosphorylates $I \kappa B \alpha$ [64], leading to its proteasome degradation and consequent release and activation of NF-KB [64]. Thus, stress stimuli activate NF-KB nuclear translocation and the downstream upregulation of its inflammatory target genes [64] (Figure 4). In such a context, several genes regulated by NF- $\mathrm{kB}$ primarily promote survival, making NF- $\mathrm{kB}$ a key player in the development of invasive tumors, metastases, and resistance to several chemotherapeutic agents [65]. IRE1 is the key molecule responsible for the integration between UPR signaling and inflammatory response; during ER stress, the complex TRAF2/IRE1 is responsible for activation of NF- $k B$, as reported by Hu et al. [66] (Figure 4). Indeed, both NF- $\kappa B$ activity and I $\kappa B \alpha$ degradation depend on IRE1 and are down-regulated in IRE1 $\alpha$-deficient cells, even though the exact mechanism used by IRE1 $\alpha$ to regulate IKK activity is still unclear. In such a context, TRAF2 can also recruit and activate the pro-inflammatory pathway mediated by JNK and AP1 [67]. Altogether, this evidence supports the concept that ER signaling regulates important physiological or pathological processes and is responsible for the subtle balance between cell survival and death through the modulation of autophagy and bioenergetic and biosynthetic pathways [68]. 


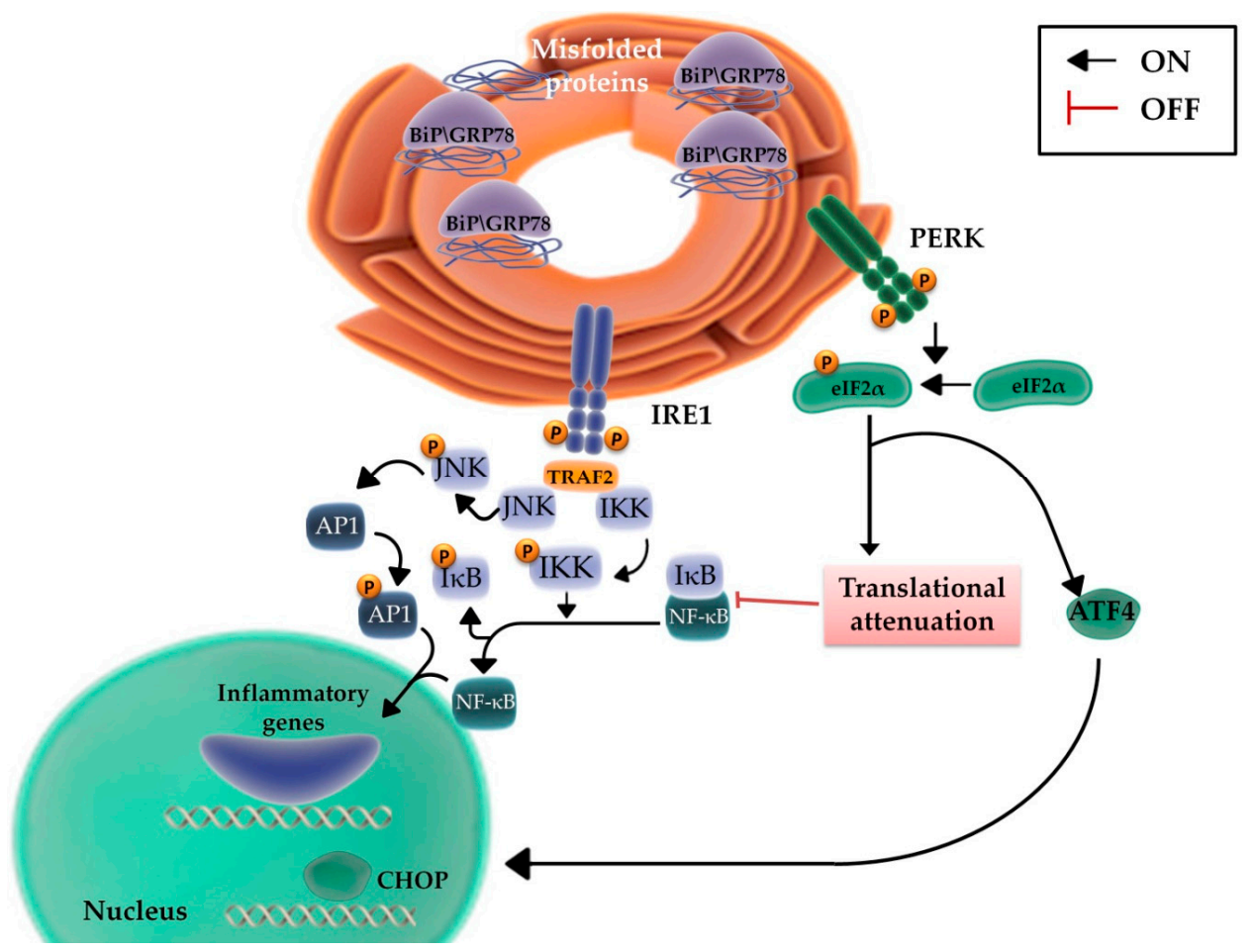

Figure 4. UPR-associated inflammatory signaling pathways. The activation of NF- $\mathrm{kB}$ requires the phosphorylation of its inhibitor, I $\mathrm{K} B \alpha$, via IKK, leading to I $\mathrm{K} B \alpha$ proteasome degradation and the consequent release of NF-KB in its active form. During ER stress, activated IRE1 forms a complex with TRAF2 and activates IKK, which in turn induces IKB degradation, the subsequent activation of NF- $\mathrm{B}$ and the transcription of pro-inflammatory genes. TRAF2 also induces the phosphorylation of JNK and the up-regulation of other pro-inflammatory genes through activated AP1. Furthermore, activated PERK promotes NF- $\kappa$ B activation via translational attenuation of I $\mathrm{B}$ [69].

\section{Endoplasmic Reticulum Stress and UPR in Breast Cancer and Their Involvement in Drug Resistance}

Breast cancer (BC) is the most common cancer in women and the second most common cause of cancer mortality; it has been estimated that almost 40,000 women die of breast cancer each year in USA [70]. It has been widely proposed that aberrant activation of UPR as well as the upregulation of UPR components are involved in BC progression and in resistance to apoptosis and drug therapy in BC cells [59].

\subsection{Aberrant UPR Activation in Breast Cancer}

The activation of the PERK-ATF4 axis is necessary for the progression of the breast tumors, having been demonstrated in both in vivo and in vitro BC cells models [71]. Indeed, the dysregulation of the PERK arm involves the activation of a series of signaling pathways that promote cell survival, and this occurs through the induction of a detoxifying action pathway, in which NRF2 plays a prominent role [72,73], or through the regulation of autophagy [74]. Consistently, the inhibition of PERK pathway enables the resensitization of BC cells to radiation [74]. However, this conclusion should be taken with caution since it has also been proposed that autophagy can be regulated by ATF4, independently of PERK [75], and that the activation of the autophagic pathway by PERK-ATF4 can also cause an imbalance towards apoptosis, transforming a pro-survival signal into a pro-death one [76]. Therefore, further studies are needed to clarify the exact molecular mechanism involved in the balance between pro-survival and pro-death signals linked to ER stress in breast carcinogenesis. 


\subsection{UPR Activation and Drug Resistance in Breast Cancer}

Several studies evaluated the role of GRP78 and XBP1 as drivers of drug resistance, based on the general observation that they are upregulated in BCs compared with normal tissue $[77,78]$. In such a context, both GRP78 and XBP1 are involved in resistance to endocrine therapy, molecular-targeted agents, and traditional chemotherapeutics $[59,79]$.

Luminal BC, the most common BC subtype (over $70 \%$ of all BCs), expresses estrogen receptor- $\alpha$ (ESR1; ER $\alpha$ ) and is successfully treated with ER $\alpha$-targeted therapies, which include receptor antagonists, such as tamoxifen or fulvestrant, and aromatase inhibitors that interfere in $17 \beta$-estradiol ligand production, such as anastrazole and letrozole [80]. Unfortunately, about half of ER $\alpha$ positive metastatic BCs respond to first line endocrine therapies, the remainders being de novo resistant $[81,82]$, and many initially responsive tumors develop resistance to these agents [82,83]. Several mechanisms are responsible for resistance to endocrine therapy, as previously reviewed in References [5,82], and among them, the activation of the UPR pathway. In this context, a hypoxic tumor environment and glucose deprivation are involved in resistance to endocrine therapy, being responsible for a prolonged UPR activation $[12,77,78]$, and GRP78 has a critical role as a regulator of endocrine responsiveness [9,79]. Mechanistically, estrogen induces the expression of GRP78 and XBP1 [78,84], both being UPR components overexpressed in, respectively, $60-70 \%$ and $80-90 \%$ human BCs $[10,84]$ and GRP78 allows estrogen-dependent cells to survive in conditions of estrogen deprivation by binding and inhibiting the proapoptotic protein BCL-2 interacting killer (Bik) [13]. Furthermore, GRP78 overexpression prevents tamoxifen effectiveness, whereas its knockdown confers sensitivity to endocrine therapy $[85,86]$. Finally, Cook et al. demonstrated that GRP78 promotes acquired, but not de novo, resistance to tamoxifen in a rat model of mammary tumors [9].

UPR activation and XBP1 upregulation have been largely described in both ER $\alpha+$ and ER $\alpha-$ BCs [82]. The crucial role of XBP1 in resistance to anti-estrogen therapy was initially predicted in an expression network study and confirmed using gene expression analysis on human $\mathrm{BC}$ specimens. Indeed, the UPR signature that includes XBP1 upregulation has been identified as a marker predictive of tamoxifen resistance in ER-positive $\mathrm{BCs}$ and has been associated with reduced time to recurrence (TTR) and poor survival [7]. In such a context, DNA microarray analysis clarified that XBP1 is an estrogen-responsive gene, expressed within the luminal cluster. The estrogen-dependent regulation of XBP1 expression was validated using different groups: XBP1 regions analysis identified ER $\alpha$-regulated promoters, linking XBP1 transcription to ER $\alpha$ and estrogen signaling [87], and this was confirmed via chromatin immunoprecipitation experiments [88]. The transcriptional activity of ER $\alpha$ on XBP1 is associated to decreased sensitivity to endocrine therapy in tumors that express both proteins [6]. XBP1 has important growth functions: it regulates genes associated with cell cycle preventing cell cycle arrest and apoptosis, inhibits the mitochondrial apoptotic cascade and estrogen responsiveness in ER- $\alpha$ positive BC cells [89]. Finally, ER $\alpha$ signaling mediates a cytoprotective UPR in mitochondria in the presence of the accumulation of unfolded proteins in $\mathrm{BC}$ cells. The estrogen-independent activation of ER $\alpha$ induces a gene expression reprogramming with an increase of the proteasome activity and protection of organelles [90].

As previously mentioned, GRP78's role in drug resistance is not restricted to endocrine therapy and to ER-positive BCs, being involved in resistance to anthracyclines $[82,86]$ and being its expression elevated in different BC subtypes, such as HER2-like [91]. Indeed, the GRP78 protein level is also involved in the resistance to trastuzumab (Herceptin), a recombinant humanized monoclonal antibody that recognizes HER2 and is active in HER2-positive BCs [92]. The overexpression of HER2, primarily due to gene amplification, occurs in approximately $25-30 \%$ of invasive human BCs [93] and its downstream signaling pathway is responsible for several features of $\mathrm{BC}$ cells, i.e., cell proliferation and migration, resistance to apoptosis, activation of the angiogenic cascade, and the metastatic process [94]. Tastuzumab was approved by the FDA for the treatment of HER2-positive BCs in the adjuvant, neoadjuvant, and metastatic settings [95], based on the paradigm that the overexpression/amplification of the HER2 receptor represents a prognostic and predictive marker and a therapeutic target [94]. 
Proteomic profiling of trastuzumab-sensitive and resistant BC cells identified GRP78 among many putative mediators of drug resistance [94]. Furthermore, Kumandan et al. demonstrated the importance of the UPR as a potential mechanism to override the activity of trastuzumab and induce resistance through the activation of the PI3K/AKT axis and the overexpression of downstream oncogenes, such as Lipocalin 2 (LCN2) [96]. Indeed, ER stress and the attendant UPR represent a possible alternative way through which PI3K/AKT signaling is reactivated during HER2 inhibition by trastuzumab, ultimately leading to the upregulation of LCN2, hence potentially resulting in trastuzumab resistance.

Finally, the GRP78 protein level has important implications in the resistance to chemotherapeutics: breast tumors with GRP78 overexpression are indeed characterized by doxorubicin ineffectiveness [11]. Furthermore, GRP78 levels were found positively associated with shorter TTR in a cohort of BC patients treated with adriamycin-based chemotherapy and consequently proposed as a predictive factor of poor responsiveness to chemotherapy $[11,86]$.

\section{Molecular Chaperones in Protection from ER Stress and Drug Resistance in BC Cells}

Molecular chaperones are responsible for correct protein folding in sub-cellular organelles and protection from ER stress and their upregulation represents an important adaptive mechanism frequently involved in human disease [1]. Indeed, cancer cells upregulate molecular chaperones to optimize protein synthesis and conjugate their increased metabolic and biosynthetic requirements with accelerated cell proliferation [14]. In such a view, molecular chaperones are key players in the intricate mechanism linking ER stress protection and metabolic rewiring to tumor progression and resistance to pharmacological agents [84]. It is well known that different molecular chaperones are overexpressed in breast cancer, i.e., Hsp90 and its mitochondrial homologues TRAP1, Hsp70, and Hsp27 [97]. Hsp90 and Hsp70 act as ATP-dependent chaperones, while Hsp27 acts as an ATP-independent chaperone [98].

\subsection{TRAP1 (HSP75)}

TRAP1 is a molecular chaperone with a prevalent mitochondrial localization and is selectively up-regulated in several human malignancies, including BC $[99,100]$. TRAP1 is characterized by antioxidant and antiapoptotic functions [101], and is involved in the protection against antiblastic agents, favoring a multidrug resistance phenotype $[99,100]$. Our group described a novel TRAP1 function outside mitochondria, at the interface between ER and mitochondria [99,102], where this chaperone interacts with the 19S proteasome subunit, 26S Proteasome AAA-ATPase Subunit RPT3 (TBP7), performing a quality control on a network of specific client proteins [102]. Noteworthy, this TRAP1 function is crucial for protein homeostasis, since TRAP1 attenuates global protein synthesis, whereas its silencing is associated with increased ubiquitination/degradation of nascent stress-protective client proteins [103]. Finally, this mechanism is responsible for cytoprotective functions and is highly conserved in human malignances supporting the concept that this pathway is relevant in drug resistance and tumor progression $[88,89]$.

A mechanistic link was demonstrated between the upregulation of TRAP1 protein network, its capacity to modulate protein synthesis and prevent ER stress and resistance to paclitaxel and anthracyclins in human BCs $[104,105]$. Indeed, taxanes and anthracyclins are cytotoxic agents widely employed in the treatment of human BC [81] and are responsible for inducing ER stress in cancer cells $[5,80]$. TRAP1 cytoprotective activity toward these chemotherapeutics strongly relies on its capacity to protect itself from ER stress, being the molecular chaperone upregulated in about $50 \%$ of human BCs and co-expressed with the ER stress marker, GRP78 [104,105]. Mechanistically, ER-associated TRAP1 is responsible for quality control on $18 \mathrm{kDa}$ Sorcin, a TRAP1 mitochondrial client protein involved in TRAP1 cytoprotective pathway, and consequently modulates mitochondrial apoptosis, and, thus favors resistance to paclitaxel and anthracyclins [100,104,105]. 


\subsection{HSP90}

Hsp90 is a molecular chaperone that assists other proteins to fold properly, and, among several others, HER2 was described as a Hsp90 client protein [106]. In addition, preclinical studies pointed the attention on a mutual regulation between HER2 and Hsp90 [107]. Thus, based on this evidence, Hsp90 has been widely studied as a molecular target in human HER2-positive BC cells [24,106]. However, it should be emphasized that the therapeutic effect of Hsp90 inhibitors as single agents or in combination with antibody directed against HER2 did not produce satisfactory results [24] and this is likely due to compensatory effects promoted by Hsp90 inhibition, promoting the up-regulation of Hsp70 and Hsp27 [24]. Furthermore, pre-clinical studies correlated Hsp90 overexpression with aggressive behavior [108], and with self-renewal in BC stem cells [109,110], suggesting the importance of this chaperone in the regulation of $\mathrm{BC}$ metabolism.

\section{3. $H S P 27$}

Hsp27 (also called HspB1) is a small heat shock protein, mainly involved in protein folding and upregulated in cells exposed to stress conditions [111]. Several studies linked Hsp27 to ER stress [112], activation of autophagy [113,114], and protection from apoptosis and drug resistance [115], based on the observation that the molecular chaperone is overexpressed in many human malignancies, including BCs [116]. Zhang D. et al. reported that Hsp27 is specifically upregulated in HER2-positive breast tumors [117], and different authors found that the upregulation of Hsp27 in BC cells reduces trastuzumab sensitivity by increasing HER2 protein stability [118] and reduces doxorubicin susceptibility by inhibiting the apoptotic cascade [119]. Consistent with a mutual cooperation between molecular chaperones, Lee C-H et al. reported that the inhibition of Hsp27 potentiates the activity of Hsp90 inhibitors in BC stem-like cells [120].

\section{Future Prospective: Autophagy and UPR as Novel Molecular Targets}

The evolution in the knowledge of ER functions allowed for the identification of numerous roles for ER in physiology and pathology. The deeper understanding of this organelle and its homeostatic regulators, the UPR response, provided relevant opportunities to exploit this information on multiple fronts. The UPR integrates different cellular processes from protein folding to the control of transcription and translation, from protein degradation to the regulation of signaling pathways responsible for cell fate. Chronic activation of UPR is a general feature of cancer cells and it is considered a mechanism of tumor progression and resistance to apoptosis and anticancer agents. In such a perspective, ER stress regulators are presently considered novel molecular biomarkers of prognosis, as well as potential targets for therapeutic interventions. In BC, the treatment with ER $\alpha$ targeting therapies and cytotoxic agents induces the activation of pro-survival UPR pathways conferring intrinsic resistance to endocrine and molecular-targeted agents and chemotherapeutics through a mechanism driven by GPR78 and XBP1 upregulation. In such a scenario, a possible pharmaceutical strategy to counteract tumor progression and drug resistance is to target UPR pro-survival components and the complex interplay between UPR, autophagy, and apoptosis, thus favoring a shift toward cell death instead of cell survival. Indeed, Cook et al. explored GRP78 and autophagy as potential targets to overcome endocrine responsiveness in ER $\alpha$-positive BC cells. They observed that GRP78 integrates signaling pathways involving UPR and autophagy and that the simultaneous knockdown of GRP78 and beclin-1 re-establishes sensitivity to antiestrogen therapy in resistant cells [9]. Furthermore, GRP78 was investigated as a target to deliver cytotoxic peptides or suicide transgene in BC in vivo. A GRP78-binding peptide fused to a pro-apoptotic moiety (i.e., BMTP78) was evaluated to selectively kill GRP78-positive BC cells. Indeed, BMTP78 was shown to inhibit primary tumor growth and the metastatic cascade in preclinical BC models [121]. Other authors used GRP78 overexpression in inflammatory BCs to deliver the human herpes simplex virus thymidine kinase type-1 (HSVtk) transgene. Interestingly, GRP78-targeting by adeno-associated virus/phage (AAVP) particles resulted 
in cytotoxic activity toward tumor cells by selective activation of the prodrug ganciclovir at tumor sites [122].

In recent years, autophagy has been proposed as an innovative target for anticancer interventions with the introduction of autophagy inhibitors as potential anticancer drugs [82]. Multiple agents are active inhibitors of different phases of autophagy, but the only clinically-approved autophagy inhibitor is an anti-malarial chloroquine and its derivatives, such as hydroxychloroquine (HCQ) [123]. HCQ inhibits lysosomal acidification and prevents the degradation of autophagosomes, thereby suppressing autophagy. HCQ treatment induces a prolonged growth arrest in vitro, and preclinical studies showed that the inhibition of autophagy by HCQ is able to overcome chemotherapeutic resistance in several tumor cell lines and animal cancer models [124]. In ER $\alpha$-positive BC cell lines, combination therapy with HCQ and tamoxifen showed superior activity compared to endocrine monotherapy [125]. Consistently, HCQ showed the capacity to potentiate the anticancer activity of bortezomib, temozolomide, temsirolimus, and doxorubicin in several cancer models, and an HCQ single agent showed clinical activity in patients with melanoma, colorectal cancer, myeloma, and renal cell carcinoma [123]. While this evidence represents the proof of concept that targeting autophagy may provide a valid anticancer strategy, future directions in this field need to identify (i) novel and more selective inhibitors of autophagy or UPR transducers, (ii) subsets of patients that are likely susceptible to autophagy inhibition, and (iii) novel predictive biomarkers to select these tumors for clinical interventions.

Funding: This work was supported by AIRC (Grant IG2015 Id.16738).

Conflicts of Interest: The authors declare no conflict of interest.

\section{References}

1. Wang, M.; Kaufman, R.J. Protein misfolding in the endoplasmic reticulum as a conduit to human disease. Nature 2016, 529, 326-335. [CrossRef] [PubMed]

2. Bravo, R.; Parra, V.; Gatica, D.; Rodriguez, A.E.; Torrealba, N.; Paredes, F.; Wang, Z.V.; Zorzano, A.; Hill, J.A.; Jaimovich, E.; et al. Endoplasmic reticulum and the unfolded protein response: Dynamics and metabolic integration. Int. Rev. Cell Mol. Biol. 2013, 301, 215-290. [CrossRef] [PubMed]

3. Fulda, S.; Gorman, A.M.; Hori, O.; Samali, A. Cellular stress responses: Cell survival and cell death. Int. J. Cell Biol. 2010, 2010, 214074. [CrossRef] [PubMed]

4. Urra, H.; Dufey, E.; Avril, T.; Chevet, E.; Hetz, C. Endoplasmic Reticulum Stress and the Hallmarks of Cancer. Trends Cancer 2016, 2, 252-262. [CrossRef]

5. Clarke, R.; Shajahan, A.N.; Wang, Y.; Tyson, J.J.; Riggins, R.B.; Weiner, L.M.; Bauman, W.T.; Xuan, J.; Zhang, B.; Facey, C.; et al. Endoplasmic reticulum stress, the unfolded protein response, and gene network modeling in antiestrogen resistant breast cancer. Horm. Mol. Biol. Clin. Investig. 2011, 5, 35-44. [CrossRef]

6. Clarke, R.; Cook, K.L. Unfolding the Role of Stress Response Signaling in Endocrine Resistant Breast Cancers. Front. Oncol. 2015, 5, 140. [CrossRef]

7. Andruska, N.; Zheng, X.; Yang, X.; Helferich, W.G.; Shapiro, D.J. Anticipatory estrogen activation of the unfolded protein response is linked to cell proliferation and poor survival in estrogen receptor alpha-positive breast cancer. Oncogene 2015, 34, 3760-3769. [CrossRef]

8. Rajapaksa, G.; Nikolos, F.; Bado, I.; Clarke, R.; Gustafsson, J.A.; Thomas, C. ERbeta decreases breast cancer cell survival by regulating the IRE1/XBP-1 pathway. Oncogene 2015, 34, 4130-4141. [CrossRef]

9. Cook, K.L.; Shajahan, A.N.; Warri, A.; Jin, L.; Hilakivi-Clarke, L.A.; Clarke, R. Glucose-regulated protein 78 controls cross-talk between apoptosis and autophagy to determine antiestrogen responsiveness. Cancer Res. 2012, 72, 3337-3349. [CrossRef]

10. Chen, X.; Iliopoulos, D.; Zhang, Q.; Tang, Q.; Greenblatt, M.B.; Hatziapostolou, M.; Lim, E.; Tam, W.L.; Ni, M.; Chen, Y.; et al. XBP1 promotes triple-negative breast cancer by controlling the HIF1alpha pathway. Nature 2014, 508, 103-107. [CrossRef]

11. Cook, K.L.; Clarke, P.A.; Clarke, R. Targeting GRP78 and antiestrogen resistance in breast cancer. Future Med. Chem. 2013, 5, 1047-1057. [CrossRef] [PubMed] 
12. Davies, M.P.; Barraclough, D.L.; Stewart, C.; Joyce, K.A.; Eccles, R.M.; Barraclough, R.; Rudland, P.S.; Sibson, D.R. Expression and splicing of the unfolded protein response gene XBP-1 are significantly associated with clinical outcome of endocrine-treated breast cancer. Int. J. Cancer 2008, 123, 85-88. [CrossRef] [PubMed]

13. Fu, Y.; Li, J.; Lee, A.S. GRP78/BiP inhibits endoplasmic reticulum BIK and protects human breast cancer cells against estrogen starvation-induced apoptosis. Cancer Res. 2007, 67, 3734-3740. [CrossRef] [PubMed]

14. Almanza, A.; Carlesso, A.; Chintha, C.; Creedican, S.; Doultsinos, D.; Leuzzi, B.; Luis, A.; McCarthy, N.; Montibeller, L.; More, S.; et al. Endoplasmic reticulum stress signalling - from basic mechanisms to clinical applications. FEBS J. 2019, 286, 241-278. [CrossRef] [PubMed]

15. Fu, X.L.; Gao, D.S. Endoplasmic reticulum proteins quality control and the unfolded protein response: The regulative mechanism of organisms against stress injuries. Biofactors 2014, 40, 569-585. [CrossRef] [PubMed]

16. Williams, D.B. Beyond lectins: The calnexin/calreticulin chaperone system of the endoplasmic reticulum. J. Cell Sci. 2006, 119, 615-623. [CrossRef] [PubMed]

17. Ishida, Y.; Nagata, K. Hsp47 as a collagen-specific molecular chaperone. Methods Enzymol. 2011, 499, $167-182$. [CrossRef] [PubMed]

18. Hirsch, C.; Gauss, R.; Horn, S.C.; Neuber, O.; Sommer, T. The ubiquitylation machinery of the endoplasmic reticulum. Nature 2009, 458, 453-460. [CrossRef]

19. Coe, H.; Michalak, M. Calcium binding chaperones of the endoplasmic reticulum. Gen. Physiol. Biophys. 2009, 28, F96-F103.

20. Bhandary, B.; Marahatta, A.; Kim, H.R.; Chae, H.J. An involvement of oxidative stress in endoplasmic reticulum stress and its associated diseases. Int. J. Mol. Sci. 2012, 14, 434-456. [CrossRef]

21. Carrara, M.; Prischi, F.; Ali, M.M. UPR Signal Activation by Luminal Sensor Domains. Int. J. Mol. Sci. 2013, 14, 6454-6466. [CrossRef] [PubMed]

22. Bertolotti, A.; Zhang, Y.; Hendershot, L.M.; Harding, H.P.; Ron, D. Dynamic interaction of BiP and ER stress transducers in the unfolded-protein response. Nat. Cell Biol. 2000, 2, 326-332. [CrossRef] [PubMed]

23. Shen, J.; Chen, X.; Hendershot, L.; Prywes, R. ER stress regulation of ATF6 localization by dissociation of BiP/GRP78 binding and unmasking of Golgi localization signals. Dev. Cell 2002, 3, 99-111. [CrossRef]

24. Sannino, S.; Brodsky, J.L. Targeting protein quality control pathways in breast cancer. BMC Biol. 2017, 15, 109. [CrossRef] [PubMed]

25. Gutierrez, T.; Simmen, T. Endoplasmic reticulum chaperones tweak the mitochondrial calcium rheostat to control metabolism and cell death. Cell Calcium 2018, 70, 64-75. [CrossRef] [PubMed]

26. Hillary, R.F.; FitzGerald, U. A lifetime of stress: ATF6 in development and homeostasis. J. Biomed. Sci. 2018, 25, 48. [CrossRef] [PubMed]

27. Lee, A.H.; Iwakoshi, N.N.; Glimcher, L.H. XBP-1 regulates a subset of endoplasmic reticulum resident chaperone genes in the unfolded protein response. Mol. Cell Biol. 2003, 23, 7448-7459. [CrossRef] [PubMed]

28. Okada, T.; Yoshida, H.; Akazawa, R.; Negishi, M.; Mori, K. Distinct roles of activating transcription factor 6 (ATF6) and double-stranded RNA-activated protein kinase-like endoplasmic reticulum kinase (PERK) in transcription during the mammalian unfolded protein response. Biochem. J. 2002, 366, 585-594. [CrossRef] [PubMed]

29. Wu, J.; Rutkowski, D.T.; Dubois, M.; Swathirajan, J.; Saunders, T.; Wang, J.; Song, B.; Yau, G.D.; Kaufman, R.J. ATF6alpha optimizes long-term endoplasmic reticulum function to protect cells from chronic stress. Dev. Cell 2007, 13, 351-364. [CrossRef]

30. Rozpedek, W.; Pytel, D.; Mucha, B.; Leszczynska, H.; Diehl, J.A.; Majsterek, I. The Role of the PERK/eIF2alpha/ATF4/CHOP Signaling Pathway in Tumor Progression During Endoplasmic Reticulum Stress. Curr. Mol. Med. 2016, 16, 533-544. [CrossRef]

31. Pakos-Zebrucka, K.; Koryga, I.; Mnich, K.; Ljujic, M.; Samali, A.; Gorman, A.M. The integrated stress response. EMBO Rep. 2016, 17, 1374-1395. [CrossRef] [PubMed]

32. Wu, R.; Zhang, Q.H.; Lu, Y.J.; Ren, K.; Yi, G.H. Involvement of the IRE1alpha-XBP1 pathway and XBP1s-dependent transcriptional reprogramming in metabolic diseases. DNA Cell Biol. 2015, 34, 6-18. [CrossRef] [PubMed]

33. Preston, G.M.; Brodsky, J.L. The evolving role of ubiquitin modification in endoplasmic reticulum-associated degradation. Biochem. J. 2017, 474, 445-469. [CrossRef] [PubMed]

34. Jain, B.P. An Overview of Unfolded Protein Response Signaling and Its Role in Cancer. Cancer Biother. Radiopharm. 2017, 32, 275-281. [CrossRef] [PubMed] 
35. Avril, T.; Vauleon, E.; Chevet, E. Endoplasmic reticulum stress signaling and chemotherapy resistance in solid cancers. Oncogenesis 2017, 6, e373. [CrossRef] [PubMed]

36. Swart, C.; Du Toit, A.; Loos, B. Autophagy and the invisible line between life and death. Eur. J. Cell Biol. 2016, 95, 598-610. [CrossRef] [PubMed]

37. Jin, S.; Wei, J.; You, L.; Liu, H.; Qian, W. Autophagy regulation and its dual role in blood cancers: A novel target for therapeutic development (Review). Oncol. Rep. 2018, 39, 2473-2481. [CrossRef]

38. Yun, C.W.; Lee, S.H. The Roles of Autophagy in Cancer. Int. J. Mol. Sci. 2018, 19. [CrossRef]

39. Song, S.; Tan, J.; Miao, Y.; Zhang, Q. Crosstalk of ER stress-mediated autophagy and ER-phagy: Involvement of UPR and the core autophagy machinery. J. Cell Physiol. 2018, 233, 3867-3874. [CrossRef]

40. Green, D.R.; Levine, B. To be or not to be? How selective autophagy and cell death govern cell fate. Cell 2014, 157, 65-75. [CrossRef]

41. Song, S.; Tan, J.; Miao, Y.; Li, M.; Zhang, Q. Crosstalk of autophagy and apoptosis: Involvement of the dual role of autophagy under ER stress. J. Cell Physiol. 2017, 232, 2977-2984. [CrossRef] [PubMed]

42. Gomes, L.R.; Menck, C.F.M.; Leandro, G.S. Autophagy Roles in the Modulation of DNA Repair Pathways. Int. J. Mol. Sci. 2017, 18. [CrossRef] [PubMed]

43. Szegezdi, E.; Macdonald, D.C.; Ni Chonghaile, T.; Gupta, S.; Samali, A. Bcl-2 family on guard at the ER. Am. J. Physiol. Cell Physiol. 2009, 296, C941-953. [CrossRef] [PubMed]

44. Li, Y.; Guo, Y.; Tang, J.; Jiang, J.; Chen, Z. New insights into the roles of CHOP-induced apoptosis in ER stress. Acta Biochim. Biophys. Sin. 2015, 47, 146-147. [CrossRef] [PubMed]

45. Marciniak, S.J.; Yun, C.Y.; Oyadomari, S.; Novoa, I.; Zhang, Y.; Jungreis, R.; Nagata, K.; Harding, H.P.; Ron, D. $\mathrm{CHOP}$ induces death by promoting protein synthesis and oxidation in the stressed endoplasmic reticulum. Genes Dev. 2004, 18, 3066-3077. [CrossRef]

46. Zinszner, H.; Kuroda, M.; Wang, X.; Batchvarova, N.; Lightfoot, R.T.; Remotti, H.; Stevens, J.L.; Ron, D. CHOP is implicated in programmed cell death in response to impaired function of the endoplasmic reticulum. Genes Dev. 1998, 12, 982-995. [CrossRef] [PubMed]

47. Iurlaro, R.; Munoz-Pinedo, C. Cell death induced by endoplasmic reticulum stress. FEBS J. 2016, 283, 2640-2652. [CrossRef]

48. Shalini, S.; Dorstyn, L.; Dawar, S.; Kumar, S. Old, new and emerging functions of caspases. Cell Death Differ. 2015, 22, 526-539. [CrossRef]

49. Sano, R.; Reed, J.C. ER stress-induced cell death mechanisms. Biochim. Biophys. Acta 2013, 1833, 3460-3470. [CrossRef]

50. Szegezdi, E.; Logue, S.E.; Gorman, A.M.; Samali, A. Mediators of endoplasmic reticulum stress-induced apoptosis. EMBO Rep. 2006, 7, 880-885. [CrossRef]

51. Elmore, S. Apoptosis: A review of programmed cell death. Toxicol. Pathol. 2007, 35, 495-516. [CrossRef] [PubMed]

52. Hotamisligil, G.S.; Davis, R.J. Cell Signaling and Stress Responses. Cold Spring Harb. Perspect. Biol. $2016,8$. [CrossRef]

53. Ladiges, W.C.; Knoblaugh, S.E.; Morton, J.F.; Korth, M.J.; Sopher, B.L.; Baskin, C.R.; MacAuley, A.; Goodman, A.G.; LeBoeuf, R.C.; Katze, M.G. Pancreatic beta-cell failure and diabetes in mice with a deletion mutation of the endoplasmic reticulum molecular chaperone gene P58IPK. Diabetes 2005, 54, 1074-1081. [CrossRef] [PubMed]

54. Maurel, M.; Chevet, E.; Tavernier, J.; Gerlo, S. Getting RIDD of RNA: IRE1 in cell fate regulation. Trends Biochem. Sci. 2014, 39, 245-254. [CrossRef] [PubMed]

55. Nishitoh, H.; Saitoh, M.; Mochida, Y.; Takeda, K.; Nakano, H.; Rothe, M.; Miyazono, K.; Ichijo, H. ASK1 is essential for JNK/SAPK activation by TRAF2. Mol. Cell 1998, 2, 389-395. [CrossRef]

56. Deng, X.; Xiao, L.; Lang, W.; Gao, F.; Ruvolo, P.; May, W.S., Jr. Novel role for JNK as a stress-activated Bcl2 kinase. J. Biol. Chem. 2001, 276, 23681-23688. [CrossRef] [PubMed]

57. Kim, I.; Shu, C.W.; Xu, W.; Shiau, C.W.; Grant, D.; Vasile, S.; Cosford, N.D.; Reed, J.C. Chemical biology investigation of cell death pathways activated by endoplasmic reticulum stress reveals cytoprotective modulators of ASK1. J. Biol. Chem. 2009, 284, 1593-1603. [CrossRef] [PubMed]

58. Puthalakath, H.; O’Reilly, L.A.; Gunn, P.; Lee, L.; Kelly, P.N.; Huntington, N.D.; Hughes, P.D.; Michalak, E.M.; McKimm-Breschkin, J.; Motoyama, N.; et al. ER stress triggers apoptosis by activating BH3-only protein Bim. Cell 2007, 129, 1337-1349. [CrossRef] 
59. McGrath, E.P.; Logue, S.E.; Mnich, K.; Deegan, S.; Jager, R.; Gorman, A.M.; Samali, A. The Unfolded Protein Response in Breast Cancer. Cancers 2018, 10. [CrossRef]

60. Yamaguchi, H.; Wang, H.G. CHOP is involved in endoplasmic reticulum stress-induced apoptosis by enhancing DR5 expression in human carcinoma cells. J. Biol. Chem. 2004, 279, 45495-45502. [CrossRef]

61. Kim, C.; Kim, B. Anti-Cancer Natural Products and Their Bioactive Compounds Inducing ER Stress-Mediated Apoptosis: A Review. Nutrients 2018, 10. [CrossRef] [PubMed]

62. Rao, R.V.; Hermel, E.; Castro-Obregon, S.; del Rio, G.; Ellerby, L.M.; Ellerby, H.M.; Bredesen, D.E. Coupling endoplasmic reticulum stress to the cell death program. Mechanism of caspase activation. J. Biol. Chem. 2001, 276, 33869-33874. [CrossRef] [PubMed]

63. Minakshi, R.; Rahman, S.; Jan, A.T.; Archana, A.; Kim, J. Implications of aging and the endoplasmic reticulum unfolded protein response on the molecular modality of breast cancer. Exp. Mol. Med. 2017, 49, e389. [CrossRef] [PubMed]

64. Schmitz, M.L.; Shaban, M.S.; Albert, B.V.; Gokcen, A.; Kracht, M. The Crosstalk of Endoplasmic Reticulum (ER) Stress Pathways with NF-kappaB: Complex Mechanisms Relevant for Cancer, Inflammation and Infection. Biomedicines 2018, 6. [CrossRef] [PubMed]

65. Basseres, D.S.; Baldwin, A.S. Nuclear factor-kappaB and inhibitor of kappaB kinase pathways in oncogenic initiation and progression. Oncogene 2006, 25, 6817-6830. [CrossRef] [PubMed]

66. Hu, P.; Han, Z.; Couvillon, A.D.; Kaufman, R.J.; Exton, J.H. Autocrine tumor necrosis factor alpha links endoplasmic reticulum stress to the membrane death receptor pathway through IRE1alpha-mediated NF-kappaB activation and down-regulation of TRAF2 expression. Mol. Cell. Biol. 2006, 26, 3071-3084. [CrossRef]

67. Urano, F.; Wang, X.; Bertolotti, A.; Zhang, Y.; Chung, P.; Harding, H.P.; Ron, D. Coupling of stress in the ER to activation of JNK protein kinases by transmembrane protein kinase IRE1. Science 2000, 287, 664-666. [CrossRef]

68. Chaudhari, N.; Talwar, P.; Parimisetty, A.; Lefebvre d'Hellencourt, C.; Ravanan, P. A molecular web: Endoplasmic reticulum stress, inflammation, and oxidative stress. Front. Cell Neurosci. 2014, 8, 213. [CrossRef]

69. Deng, J.; Lu, P.D.; Zhang, Y.; Scheuner, D.; Kaufman, R.J.; Sonenberg, N.; Harding, H.P.; Ron, D. Translational repression mediates activation of nuclear factor kappa B by phosphorylated translation initiation factor 2. Mol. Cell Biol. 2004, 24, 10161-10168. [CrossRef]

70. Kohler, B.A.; Sherman, R.L.; Howlader, N.; Jemal, A.; Ryerson, A.B.; Henry, K.A.; Boscoe, F.P.; Cronin, K.A.; Lake, A.; Noone, A.M.; et al. Annual Report to the Nation on the Status of Cancer, 1975-2011, Featuring Incidence of Breast Cancer Subtypes by Race/Ethnicity, Poverty, and State. J. Natl. Cancer Inst. 2015, 107, djv048. [CrossRef]

71. Feng, Y.X.; Jin, D.X.; Sokol, E.S.; Reinhardt, F.; Miller, D.H.; Gupta, P.B. Cancer-specific PERK signaling drives invasion and metastasis through CREB3L1. Nat. Commun. 2017, 8, 1079. [CrossRef] [PubMed]

72. Syu, J.P.; Chi, J.T.; Kung, H.N. Nrf2 is the key to chemotherapy resistance in MCF7 breast cancer cells under hypoxia. Oncotarget 2016, 7, 14659-14672. [CrossRef] [PubMed]

73. Cullinan, S.B.; Zhang, D.; Hannink, M.; Arvisais, E.; Kaufman, R.J.; Diehl, J.A. Nrf2 is a direct PERK substrate and effector of PERK-dependent cell survival. Mol. Cell Biol. 2003, 23, 7198-7209. [CrossRef] [PubMed]

74. Nagelkerke, A.; Bussink, J.; van der Kogel, A.J.; Sweep, F.C.; Span, P.N. The PERK/ATF4/LAMP3-arm of the unfolded protein response affects radioresistance by interfering with the DNA damage response. Radiother. Oncol. 2013, 108, 415-421. [CrossRef] [PubMed]

75. Notte, A.; Rebucci, M.; Fransolet, M.; Roegiers, E.; Genin, M.; Tellier, C.; Watillon, K.; Fattaccioli, A.; Arnould, T.; Michiels, C. Taxol-induced unfolded protein response activation in breast cancer cells exposed to hypoxia: ATF4 activation regulates autophagy and inhibits apoptosis. Int. J. Biochem. Cell Biol. 2015, 62, 1-14. [CrossRef] [PubMed]

76. Wang, S.; Chen, X.A.; Hu, J.; Jiang, J.K.; Li, Y.; Chan-Salis, K.Y.; Gu, Y.; Chen, G.; Thomas, C.; Pugh, B.F.; et al. ATF4 Gene Network Mediates Cellular Response to the Anticancer PAD Inhibitor YW3-56 in Triple-Negative Breast Cancer Cells. Mol. Cancer Ther. 2015, 14, 877-888. [CrossRef]

77. Fernandez, P.M.; Tabbara, S.O.; Jacobs, L.K.; Manning, F.C.; Tsangaris, T.N.; Schwartz, A.M.; Kennedy, K.A.; Patierno, S.R. Overexpression of the glucose-regulated stress gene GRP78 in malignant but not benign human breast lesions. Breast Cancer Res. Treat. 2000, 59, 15-26. [CrossRef] 
78. Scriven, P.; Coulson, S.; Haines, R.; Balasubramanian, S.; Cross, S.; Wyld, L. Activation and clinical significance of the unfolded protein response in breast cancer. Br. J. Cancer 2009, 101, 1692-1698. [CrossRef]

79. Cook, K.L.; Clarke, R. Role of GRP78 in promoting therapeutic-resistant breast cancer. Future Med. Chem. 2015, 7, 1529-1534. [CrossRef]

80. Rajapaksa, G.; Thomas, C.; Gustafsson, J.A. Estrogen signaling and unfolded protein response in breast cancer. J. Steroid. Biochem. Mol. Biol. 2016, 163, 45-50. [CrossRef]

81. Clarke, R.; Leonessa, F.; Welch, J.N.; Skaar, T.C. Cellular and molecular pharmacology of antiestrogen action and resistance. Pharmacol. Rev. 2001, 53, 25-71. [PubMed]

82. Clarke, R.; Tyson, J.J.; Dixon, J.M. Endocrine resistance in breast cancer-An overview and update. Mol. Cell Endocrinol. 2015, 418 Pt 3, 220-234. [CrossRef]

83. Riggins, R.B.; Bouton, A.H.; Liu, M.C.; Clarke, R. Antiestrogens, aromatase inhibitors, and apoptosis in breast cancer. Vitam. Horm. 2005, 71, 201-237. [CrossRef] [PubMed]

84. Sengupta, S.; Sharma, C.G.; Jordan, V.C. Estrogen regulation of X-box binding protein-1 and its role in estrogen induced growth of breast and endometrial cancer cells. Horm. Mol. Biol. Clin. Investig. 2010, 2, 235-243. [CrossRef] [PubMed]

85. Clarke, R.; Cook, K.L.; Hu, R.; Facey, C.O.; Tavassoly, I.; Schwartz, J.L.; Baumann, W.T.; Tyson, J.J.; Xuan, J.; Wang, Y.; et al. Endoplasmic reticulum stress, the unfolded protein response, autophagy, and the integrated regulation of breast cancer cell fate. Cancer Res. 2012, 72, 1321-1331. [CrossRef] [PubMed]

86. Lee, E.; Nichols, P.; Spicer, D.; Groshen, S.; Yu, M.C.; Lee, A.S. GRP78 as a novel predictor of responsiveness to chemotherapy in breast cancer. Cancer Res. 2006, 66, 7849-7853. [CrossRef]

87. Wang, D.Y.; Fulthorpe, R.; Liss, S.N.; Edwards, E.A. Identification of estrogen-responsive genes by complementary deoxyribonucleic acid microarray and characterization of a novel early estrogen-induced gene: EEIG1. Mol. Endocrinol. 2004, 18, 402-411. [CrossRef]

88. Carroll, J.S.; Liu, X.S.; Brodsky, A.S.; Li, W.; Meyer, C.A.; Szary, A.J.; Eeckhoute, J.; Shao, W.; Hestermann, E.V.; Geistlinger, T.R.; et al. Chromosome-wide mapping of estrogen receptor binding reveals long-range regulation requiring the forkhead protein FoxA1. Cell 2005, 122, 33-43. [CrossRef]

89. Gomez, B.P.; Riggins, R.B.; Shajahan, A.N.; Klimach, U.; Wang, A.; Crawford, A.C.; Zhu, Y.; Zwart, A.; Wang, M.; Clarke, R. Human X-box binding protein-1 confers both estrogen independence and antiestrogen resistance in breast cancer cell lines. FASEB J. 2007, 21, 4013-4027. [CrossRef]

90. Papa, L.; Germain, D. Estrogen receptor mediates a distinct mitochondrial unfolded protein response. J. Cell Sci. 2011, 124, 1396-1402. [CrossRef]

91. Zhang, D.; Tai, L.K.; Wong, L.L.; Putti, T.C.; Sethi, S.K.; Teh, M.; Koay, E.S. Proteomic characterization of differentially expressed proteins in breast cancer: Expression of hnRNP H1, RKIP and GRP78 is strongly associated with HER-2/neu status. Proteomics Clin. Appl. 2008, 2, 99-107. [CrossRef] [PubMed]

92. Garrett, J.T.; Rawale, S.; Allen, S.D.; Phillips, G.; Forni, G.; Morris, J.C.; Kaumaya, P.T. Novel engineered trastuzumab conformational epitopes demonstrate in vitro and in vivo antitumor properties against HER-2/neu. J. Immunol. 2007, 178, 7120-7131. [CrossRef] [PubMed]

93. Moasser, M.M. The oncogene HER2: Its signaling and transforming functions and its role in human cancer pathogenesis. Oncogene 2007, 26, 6469-6487. [CrossRef] [PubMed]

94. Cara, G.D.; Marengo, G.; Albanese, N.N.; Marabeti, M.R.; Musso, R.; Cancemi, P.; Pucci-Minafra, I. Proteomic profiling of Trastuzumab (Herceptin(R))-sensitive and -resistant SKBR-3 breast cancer cells. Anticancer Res. 2013, 33, 489-503.

95. Vu, T.; Claret, F.X. Trastuzumab: Updated mechanisms of action and resistance in breast cancer. Front. Oncol. 2012, 2, 62. [CrossRef]

96. Kumandan, S.; Mahadevan, N.R.; Chiu, K.; DeLaney, A.; Zanetti, M. Activation of the unfolded protein response bypasses trastuzumab-mediated inhibition of the PI-3K pathway. Cancer Lett. 2013, 329, $236-242$. [CrossRef] [PubMed]

97. Calderwood, S.K. Heat shock proteins in breast cancer progression-A suitable case for treatment? Int J. Hyperthermia 2010, 26, 681-685. [CrossRef]

98. Arrigo, A.P. Mammalian HspB1 (Hsp27) is a molecular sensor linked to the physiology and environment of the cell. Cell Stress Chaperones 2017, 22, 517-529. [CrossRef] 
99. Amoroso, M.R.; Matassa, D.S.; Sisinni, L.; Lettini, G.; Landriscina, M.; Esposito, F. TRAP1 revisited: Novel localizations and functions of a 'next-generation' biomarker (review). Int. J. Oncol. 2014, 45, 969-977. [CrossRef]

100. Lettini, G.; Maddalena, F.; Sisinni, L.; Condelli, V.; Matassa, D.S.; Costi, M.P.; Simoni, D.; Esposito, F.; Landriscina, M. TRAP1: A viable therapeutic target for future cancer treatments? Expert. Opin. Ther. Targets 2017, 21, 805-815. [CrossRef]

101. Matassa, D.S.; Amoroso, M.R.; Maddalena, F.; Landriscina, M.; Esposito, F. New insights into TRAP1 pathway. Am. J. Cancer Res. 2012, 2, 235-248. [PubMed]

102. Amoroso, M.R.; Matassa, D.S.; Laudiero, G.; Egorova, A.V.; Polishchuk, R.S.; Maddalena, F.; Piscazzi, A.; Paladino, S.; Sarnataro, D.; Garbi, C.; et al. TRAP1 and the proteasome regulatory particle TBP7/Rpt3 interact in the endoplasmic reticulum and control cellular ubiquitination of specific mitochondrial proteins. Cell Death Differ. 2012, 19, 592-604. [CrossRef] [PubMed]

103. Matassa, D.S.; Amoroso, M.R.; Agliarulo, I.; Maddalena, F.; Sisinni, L.; Paladino, S.; Romano, S.; Romano, M.F.; Sagar, V.; Loreni, F.; et al. Translational control in the stress adaptive response of cancer cells: A novel role for the heat shock protein TRAP1. Cell Death Dis. 2013, 4, e851. [CrossRef] [PubMed]

104. Maddalena, F.; Sisinni, L.; Lettini, G.; Condelli, V.; Matassa, D.S.; Piscazzi, A.; Amoroso, M.R.; La Torre, G.; Esposito, F.; Landriscina, M. Resistance to paclitxel in breast carcinoma cells requires a quality control of mitochondrial antiapoptotic proteins by TRAP1. Mol. Oncol. 2013, 7, 895-906. [CrossRef] [PubMed]

105. Sisinni, L.; Maddalena, F.; Lettini, G.; Condelli, V.; Matassa, D.S.; Esposito, F.; Landriscina, M. TRAP1 role in endoplasmic reticulum stress protection favors resistance to anthracyclins in breast carcinoma cells. Int. J. Oncol. 2014, 44, 573-582. [CrossRef] [PubMed]

106. Patel, P.D.; Yan, P.; Seidler, P.M.; Patel, H.J.; Sun, W.; Yang, C.; Que, N.S.; Taldone, T.; Finotti, P.; Stephani, R.A.; et al. Paralog-selective Hsp90 inhibitors define tumor-specific regulation of HER2. Nat. Chem. Biol. 2013, 9 , 677-684. [CrossRef] [PubMed]

107. Schulz, R.; Streller, F.; Scheel, A.H.; Ruschoff, J.; Reinert, M.C.; Dobbelstein, M.; Marchenko, N.D.; Moll, U.M. HER2/ErbB2 activates HSF1 and thereby controls HSP90 clients including MIF in HER2-overexpressing breast cancer. Cell Death Dis. 2014, 5, e980. [CrossRef] [PubMed]

108. Osada, T.; Kaneko, K.; Gwin, W.R.; Morse, M.A.; Hobeika, A.; Pogue, B.W.; Hartman, Z.C.; Hughes, P.F.; Haystead, T.; Lyerly, H.K. In Vivo Detection of HSP90 Identifies Breast Cancers with Aggressive Behavior. Clin Cancer Res. 2017, 23, 7531-7542. [CrossRef]

109. Lee, Y.C.; Chang, W.W.; Chen, Y.Y.; Tsai, Y.H.; Chou, Y.H.; Tseng, H.C.; Chen, H.L.; Wu, C.C.; Chang-Chien, J.; Lee, H.T.; et al. Hsp90alpha Mediates BMI1 Expression in Breast Cancer Stem/Progenitor Cells through Facilitating Nuclear Translocation of c-Myc and EZH2. Int. J. Mol. Sci. 2017, 18. [CrossRef]

110. Stivarou, T.; Stellas, D.; Vartzi, G.; Thomaidou, D.; Patsavoudi, E. Targeting highly expressed extracellular HSP90 in breast cancer stem cells inhibits tumor growth in vitro and in vivo. Cancer Biol. Ther. 2016, 17, 799-812. [CrossRef]

111. Haslbeck, M.; Weinkauf, S.; Buchner, J. Small heat shock proteins: Simplicity meets complexity. J. Biol. Chem. 2018. [CrossRef] [PubMed]

112. Ito, H.; Iwamoto, I.; Inaguma, Y.; Takizawa, T.; Nagata, K.; Asano, T.; Kato, K. Endoplasmic reticulum stress induces the phosphorylation of small heat shock protein, Hsp27. J. Cell Biochem. 2005, 95, 932-941. [CrossRef] [PubMed]

113. Kumano, M.; Furukawa, J.; Shiota, M.; Zardan, A.; Zhang, F.; Beraldi, E.; Wiedmann, R.M.; Fazli, L.; Zoubeidi, A.; Gleave, M.E. Cotargeting stress-activated Hsp27 and autophagy as a combinatorial strategy to amplify endoplasmic reticular stress in prostate cancer. Mol. Cancer Ther. 2012, 11, 1661-1671. [CrossRef] [PubMed]

114. Livingston, J.A.; Wang, W.L.; Tsai, J.W.; Lazar, A.J.; Leung, C.H.; Lin, H.; Advani, S.; Daw, N.; Santiago-O'Farrill, J.; Hollomon, M.; et al. Analysis of HSP27 and the Autophagy Marker LC3B(+) Puncta Following Preoperative Chemotherapy Identifies High-Risk Osteosarcoma Patients. Mol. Cancer Ther. 2018, 17, 1315-1323. [CrossRef] [PubMed]

115. Sheng, B.; Qi, C.; Liu, B.; Lin, Y.; Fu, T.; Zeng, Q. Increased HSP27 correlates with malignant biological behavior of non-small cell lung cancer and predicts patient's survival. Sci. Rep. 2017, 7, 13807. [CrossRef] [PubMed] 
116. Homaei-Shandiz, F.; Mehrad-Majd, H.; Tasbandi, M.; Aledavood, A.; Tavakol Afshari, J.; Ghavami, V.; Ghayour-Mobarhan, M. Anti-Heat Shock Protein-27 Antibody Levels in Women with Breast Cancer: Association with Disease Complications and Two-Year Disease-Free Survival. Asian Pac. J. Cancer Prev. 2016, 17, 4655-4659. [PubMed]

117. Zhang, D.; Wong, L.L.; Koay, E.S. Phosphorylation of Ser78 of Hsp27 correlated with HER-2/neu status and lymph node positivity in breast cancer. Mol. Cancer 2007, 6, 52. [CrossRef] [PubMed]

118. Kang, S.H.; Kang, K.W.; Kim, K.H.; Kwon, B.; Kim, S.K.; Lee, H.Y.; Kong, S.Y.; Lee, E.S.; Jang, S.G.; Yoo, B.C. Upregulated HSP27 in human breast cancer cells reduces Herceptin susceptibility by increasing Her2 protein stability. BMC Cancer 2008, 8, 286. [CrossRef]

119. Diaz-Chavez, J.; Fonseca-Sanchez, M.A.; Arechaga-Ocampo, E.; Flores-Perez, A.; Palacios-Rodriguez, Y.; Dominguez-Gomez, G.; Marchat, L.A.; Fuentes-Mera, L.; Mendoza-Hernandez, G.; Gariglio, P.; et al. Proteomic profiling reveals that resveratrol inhibits HSP27 expression and sensitizes breast cancer cells to doxorubicin therapy. PLOS ONE 2013, 8, e64378. [CrossRef]

120. Lee, C.H.; Hong, H.M.; Chang, Y.Y.; Chang, W.W. Inhibition of heat shock protein (Hsp) 27 potentiates the suppressive effect of Hsp90 inhibitors in targeting breast cancer stem-like cells. Biochimie 2012, 94, 1382-1389. [CrossRef]

121. Miao, Y.R.; Eckhardt, B.L.; Cao, Y.; Pasqualini, R.; Argani, P.; Arap, W.; Ramsay, R.G.; Anderson, R.L. Inhibition of established micrometastases by targeted drug delivery via cell surface-associated GRP78. Clin. Cancer Res. 2013, 19, 2107-2116. [CrossRef] [PubMed]

122. Dobroff, A.S.; D’Angelo, S.; Eckhardt, B.L.; Ferrara, F.; Staquicini, D.I.; Cardo-Vila, M.; Staquicini, F.I.; Nunes, D.N.; Kim, K.; Driessen, W.H.P.; et al. Towards a transcriptome-based theranostic platform for unfavorable breast cancer phenotypes. Proc. Natl. Acad. Sci. USA 2016, 113, 12780-12785. [CrossRef] [PubMed]

123. Onorati, A.V.; Dyczynski, M.; Ojha, R.; Amaravadi, R.K. Targeting autophagy in cancer. Cancer 2018, 124, 3307-3318. [CrossRef] [PubMed]

124. Cook, K.L.; Warri, A.; Soto-Pantoja, D.R.; Clarke, P.A.; Cruz, M.I.; Zwart, A.; Clarke, R. Hydroxychloroquine inhibits autophagy to potentiate antiestrogen responsiveness in ER+ breast cancer. Clin. Cancer Res. 2014, 20, 3222-3232. [CrossRef] [PubMed]

125. Chude, C.I.; Amaravadi, R.K. Targeting Autophagy in Cancer: Update on Clinical Trials and Novel Inhibitors. Int. J. Mol. Sci. 2017, 18. [CrossRef] 